\title{
The Options and Limitations of the Brain Fingerprinting Lie Detection Method in the Criminal Proceeding ${ }^{1}$
}

\author{
BUDAHÁZI Árpád ${ }^{2}$ - FANTOLY Zsanett ${ }^{3}$ - KAKUSZI Brigitta ${ }^{4}$ - \\ BITTER István ${ }^{5}$ - CZOBOR Pál ${ }^{6}$
}

The aim of this study is to introduce the new lie detection method of brain fingerprinting already introduced in the United States of America. According to some scholars, the method of a brain-focused instrumental credibility examination of testimonies still unknown in Hungary is highly reliable, establishing their concept on their belief that the human brain does not lie. First of all, we shall examine the possibilities lying in the measure, and second of all, we shall introduce the doubts causing the delay of its admission in Hungary.

Keywords: brain fingerprinting, P300, CIT, instrumental credibility examination of testimonies, EEG, MERMER

Larry Farwell has developed a lie detecting method that directly examines the brain. The brain fingerprinting examination detects, whether specific information is stored in the human brain or not. ${ }^{7}$ The examinee is shown photographs flashed on a computer screen, amongst which some critical crime-related visual images appear. Should the brain react to the critical photo, giving a so-called 'ah' signal, ${ }^{8}$ the examiners consequently indicate, that they are testing the perpetrator. In point of fact, the 'ah' or 'yeah' signal is a 'MERMER' response, namely, Farwell has discovered a 'MERMER' signal in the brain, that is the component of the larger brain frequency known as P300. ${ }^{9} \mathrm{EEG}$ (electroencephalogram) sensors are used in the analysis to detect the electric brain functions of the subject generated by various external stimulus. In case of a MERMER

The work was created in commission of the National University of Public Service under the priority project PACSDOP2.1.2-CCHOP-15-2016-00001 entitled "Public Service Development Establishing Good Governance" in the Ludovika Research Group.

2 BUDAHÁZI Árpád, PhD, Police Major, Senior Lecturer, National University of Public Service, Faculty of Law Enforcement https://orcid.org/0000-0003-0092-3860, Budahazi.Arpad@uni-nke.hu

3 FANTOLY Zsanett, Prof. Dr., Head of Department, National University of Public Service, Faculty of Law Enforcement https://orcid.org/0000-0003-1016-0377, Fantoly.Zsanett@uni-nke.hu

4 KAKUSZI Brigitta, Research Scientist, Semmelweis University

https://orcid.org/0000-0002-9102-4096

5 BITTER István, Prof. Dr. Dsc., Professor, Semmelweis University

https://orcid.org/0000-0002-9464-4709

6 CZOBOR Pál, PhD, Associate Professor, Director of Science, Semmelweis University

https://orcid.org/0000-0002-6361-8006

Moenssens (2002) 891.

Farwell (2012) 117.

Póczos (2006) 102. 
response the examiner concludes that the information connected to the effect is stored in the subject's memory. On the contrary, irrelevant stimulus does not result in a MERMER response. ${ }^{10}$ Brain fingerprinting is a non-invasive, yet safe and painless method. ${ }^{11}$

\section{Fundamental Experiments on Operating the Brain Fingerprinting Method}

Rosenfeld and his co-researchers ${ }^{12}$ recognised that the $\mathrm{P} 300$ potential might be suitable to identify crime-related concealed information. The principal thought of the authors was that P300 brain frequencies can potentially be used to explore known familiar information stored in the memory even in cases when the examinee denies that such information (for example, on a certain object, on the surroundings or on a person) would be known to him. P300 does not mark the lie itself in such context, but only the recognition of information; however, verbal denial of this might refer to deliberate intentions of deception. Originally, the authors have used the expression 'guilty knowledge' (however, it is not precise enough and amounts to a judgement, therefore, using terms like identification of 'crime-related' or 'concealed' information could be more justifiable and more accurate) ${ }^{13}$

During the laboratory researches led by Rosenfeld and his colleagues, the examinees had to conduct a simulated criminal act. Namely, they had to steal one item out ten from a box. Later on, the name of each item was shown to the participants one by one on a screen. Upon simple visual evaluation of the P300 potentials it was determined that the objects (pretended to be) 'stolen' by the examined individuals - in other words, 'probes'- enhanced P300 potential at 9 persons out of 10 . The other 'irrelevant' objects did not enhance event-related P300 potential. They have also used another specific, occasionally interpreted stimulus as well ('target' stimulus) to which the examined individuals had to respond with a verbal answer 'yes' at each appearance. Researchers aimed to confirm that the examinees did actually focus on the screen using the target, so they could monitor the interpretation of probes stimuli. Examinees must have given a negative ('no') response to all stimuli except for the target, thus, they had to lie about the object they had 'stolen' during the examination. Being rare and having special meaning to the participants, special target stimuli (objects) could also enhance the P300 event-related potential. It should be noted that the paradigm used by Rosenfeld and his co-researchers was quite similar to the paradigm of the Guilty Knowledge Test (GKT) established by Lykken, ${ }^{14}$ later referred to as the Concealed Information Test (CIT).

\footnotetext{
Stoller-Wolpe (2007) 362.

Fox (2008) 34.

Rosenfeld et al. (1987) 125-129; Rosenfeld et al. (2013) 118-134.

Czobor et al. (2018) 53-67.

Lykken (1959) 629-634.
} 
Simultaneously with the research conducted by Rosenfeld and his partners, another group of analysts ${ }^{15}$ has recognised the possibilities offered by P300 in detecting 'concealed' traces of memories. Similarly to those of Rosenfeld and partners, they also followed the CIT analysis paradigm. Farwell and his workgroup have tested the P300 brain frequency-based method in both laboratory ('mock scene scenario') and in real life circumstances on actual offenders. Farwell's workgroup has recorded rather good statistics using the P300-based method in detecting concealed information (specific and sensitive results generally exceeded above 99\%) both at the early and at the later stage of the examinations. ${ }^{16}$ The term 'brain fingerprinting' is credited to the same workgroup, as well. According to later meta-analysis and summary reports, P300 brain waves in CIT tests enhance significantly larger efficiency and amplitudes in detecting concealed information than psychophysiological parameter measures (such as skin conductance response, respiration line length, changes in heart rate). ${ }^{17}$

\section{Adaptation of Brain Fingerprinting in the United States of America}

Brain fingerprinting is used by the FBI, the CIA and by the US Navy in the USA. ${ }^{18}$ However, the method has only been used in three criminal cases upon the studies of Farwell, inventor and first conductor of brain fingerprinting. Only in one of the three cases, namely in Terry Harrington's trial (2003) was it used in a court procedure. In James B. Grinder's case (1999) the technique was admitted during the course of investigation, however, the case terminated with a plea deal. In the Jimmy Ray Slaughter case (2004) the proceeding court rejected the admissibility of brain fingerprinting results as evidence.

\section{The Terry Harrington case}

In 1977, Terry Harrington who was 17 at the time, was accused of the murder of John Schweer, a retired police captain. The victim had been working as security guard at a car dealership, where the offence has taken place. ${ }^{19}$ In the criminal procedure, Harrington had alleged that he had been at a rock concert with friends in another town on the evening of the crime. Several witnesses corroborated the defendant's alibi. However, Kevin Hughes, primary prosecution witness who was 16 at the time, testified in contradiction to the defendant's plea, upon which Harrington was found guilty and sentenced to life without a parole. In 1997, Harrington petitioned the Iowa District Court for post-conviction relief for a new trial, and in March 2000,

\footnotetext{
Farwell-Donchin (1986) 434-450.

16 Farwell-Donchin (1991) 531-547; Farwell et al. (2013) 263-299.

17 Meijer et al. (2014) 879-904.

18 Farwell (2018a)

19 Hurd (2012) 213.
} 
he amended his petition to include the results of Farwell's brain fingerprinting testing. The applicant alleged that the results of the brain fingerprinting enhance a new evidence that was unknown to the first decree court, and upon which the defendant should have been acquitted. Farwell came to the conclusion that Harrington's brain did not store critical details of the crime subject to his conviction, for example, his brain did not recognise the crime scene. On the other hand, with regards to critical details on the alibi (he had been at a concert on the evening of the crime) Farwell concluded, that such information was stored in Harrington's brain. When confronted with the brain fingerprinting test results, Kevin Hughes, the key prosecution witness recanted his testimony and admitted that he had lied in the original trial, falsely accusing Harrington. He explained that he had lied, fearing that if he was telling the truth, he might have been accused of murder himself. ${ }^{20}$

In November 2000, the Iowa District Court held a hearing on the petition for post-conviction relief. Farwell has testified as an expert on the new method, furthermore, two acknowledged professors, William Iacono of the University of Minnesota and Emanuel Donchin of the University of Illinois have confirmed the efficiency of the Farwell-research and stated that brain fingerprinting - as a scientific method - can recall any information stored in the human brain with a $99.9 \%$ accuracy. It enhances the technique to meet the legal standards for admissibility for the authorities proceeding in criminal cases as reliable evidence. ${ }^{21}$ After an eight-hour session, the court ruled that brain fingerprinting testing met the legal standards for admissibility in court as unquestionable scientific evidence. It constituted a new evidence in the case, that could be the ground of a new trial opened upon the post-conviction petition. However, the court also ruled, that along with other newly discovered evidence in the case, it would probably not have resulted in the jury arriving at a different verdict than at the original trial, and therefore it denied the petition for a new trial. In August 2001, Harrington has filed an appeal on the Iowa District Court's decision denying a new trial, resulting that the Iowa Supreme Court ordered a new trial. ${ }^{22}$ Although, the Iowa Supreme Court has undoubtedly acknowledged Farwell's expert opinion on brain fingerprinting testing, however, the favourable closure of the case to Harrington was based on the injury of the Brady rule, thus, the defendant was not confronted with the key prosecution witness, since he recanted his testimony when confronted with the brain fingerprinting test results. In the light of the new evidence and with regards to the fact that the key prosecution witness of the original case recanted his testimony, the basis of the conviction in 2003, Harrington was released and his conviction was reversed. He has received USD 12 million compensation for the years he had spent in jail. ${ }^{23}$

\footnotetext{
Farwell (2018b)

Farwell (2018b)

Harrington v. State, 659. N.W. 2nd 509 (Iowa 2003, No. 96-1232.)

Farwell (2018b)
} 


\section{The James B. Grinder case}

James B. Grinder has been the prime suspect of the murder of 25-year-old Julie Helton, despite of the defence's conviction that the evidence was insufficient to indict him and to convict him in first-degree murder. In January 1984, the abduction of Julie Helton was reported in Macon, Missouri. The victim's body was found three days after near a railroad track in outside Macon. The coroner discovered signs of rape and physical abuse on the body, and also found a stabbed wound on the neck. During the 15-year long criminal procedure, Grinder gave several different testimonies. He soon recanted his firs testimony confessing his involvement, and denied the offence. Some of his testimonies referred to other perpetrators of the crime. However, the testimonies were invariably contradictory to the available material evidences and to the testimony of an alleged witness of the defence. Even DNA test did not bring reassuring results, since the blood samples taken at the crime scene were rather old. In 1999, Macon County Sheriff, Robert Dawson - after approximately 10,000 man-hours of unsuccessful investigation - turned to brain fingerprinting testing in order to decide, whether Grinder had committed the crime or not. Grinder, who had spent several years in prison before, agreed to the test. The Sherriff gave all significant information gathered during the investigation to Farwell, and Farwell completed the test with the cooperation of an FBI agent. The examination was completed at the correction institute where Grinder was held. During the analysis, Grinder was shown the murder weapon, specific methods of killing the victim, the object the perpetrator used to bind the victim's hands, the crime scene and the belongings of the victim found not far from the location of the offence after discovering the criminal act. Farwell came to the conclusion, that all the critical information was stored and present in Grinder's brain. In accordance with the principles of the method, the conclusion was that Grinder did commit the offence, otherwise his brain would not have enhanced MERMER responses to relevant information. However, Grinder concluded a plea deal, he pled guilty to rape and murder of the victim, and in exchange - instead of death penalty - he agreed to a life sentence without parole. Uniquely, in this case Grinder did not only confess murdering victim Julie Helton, but after the brain fingerprinting examination he gave a detailed confession to the murder of three more young girls. He first raped and then stabbed or beat his victims to death. ${ }^{24}$ As for now, there are two final and binding orders in conviction of Grinder, another procedure is still pending.

\section{The Jimmy Ray Slaughter case}

In 2004, Jimmy Ray Slaughter a death row inmate has plead for new trial referring to negative test results of brain fingerprinting (information not stored in the brain) and also to other evidences at the Court (of Criminal Appeals) of Oklahoma. The appealer

24 Farwell (2018c) 
did not only refer to the favourable results of brain fingerprinting, but also referred to the exempting results of DNS analysis and further evidence proving his innocence. ${ }^{25}$

Slaughter was condemned to death for the July 2, 1991 murder of his former girlfriend, the 29-year-old Melody Wuertz, and their child, the 11-month-old Jessica Rae Wuertz. ${ }^{26}$ The killing actions were committed in the victims' Edmond home. According to the ruling, Slaughter have shot both his victims in the head, in addition, he has shot his ex-girlfriend in the neck, moreover, he has stabbed the victim several times, and then mutilated her body. ${ }^{27}$ Slaughter has claimed innocent of the crime all along, despite of the fact that investigation proved that he had a rather bad relationship with his ex-girlfriend, and they had numerous fights and furious quarrels over unpaid child support. At the end, Slaughter was executed. Denying the petition for a new trial, the court has also referred to brain fingerprinting, stating that it did not recognise the results because the court did not receive a comprehensive description on the method, neither on the nature, nor on the application or the results of the technique. The brain fingerprinting 'evidence' would not have changed the balance of the scales before the jury - ruled the court. ${ }^{28}$

\section{The Conduct of Brain Fingerprinting in Hungary}

The adaption of the brain fingerprinting method might as well be completed in Hungary with the coming into effect of the new criminal procedural code (hereinafter the IV. Be.), ${ }^{29}$ since the new code uniformly refers to instrumental credibility examination of testimonies for all tests and analyses conducted on suspects or witnesses in order to determine, whether the examinee sincerely denies the conduct of the crime or not, or is in possession of crime-related information as he stated during the interview. The IV. Be. does not only specify polygraph examination, as the only instrumental method referred in the criminal code in force until June $30,2018,{ }^{30}$ but declares the admissibility of instrumental credibility examination of testimonies, provided that the legally mature witness or suspect agreed to the test. [Section 212 (1) IV. Be.]

There is a possibility for the adaption of the brain fingerprinting testing, nevertheless, the introduction and acknowledgement of the method in Hungary cannot be expected in the near future, taking note, as it could not gain considerable potential in criminal cases conducted in the US, in its home country either, however, it is successfully used in other fields.

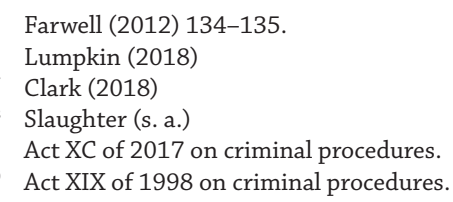




\section{Subjects of brain fingerprinting}

\section{Professional expert (counsel)}

While only professional expert counsels are permitted to conduct the examination in the US from the first (the same shall apply to the brain fingerprinting method in Hungary, after being admissible upon the coming into force of the IV. Be. in July 2018). ${ }^{31}$ Since a medical device, the EEG is used to conduct the brain fingerprinting test, the question now arises, what skills or qualifications are required for the application of brain fingerprinting. Moreover, can a former detective or investigator master the examination methodology, or otherwise a specific psychological or medical qualification is required? The higher level of qualification required, the lesser the chance of the brain fingerprinting's wide spreading, since its publicity requires brain fingerprinting examiners.

\section{Witness}

The examined individual is also a subjective category. According to Section 87 (2) of the IV. Be. the witness under the age of eighteen shall not be subject to an instrumental credibility examination. Consequently, only mature witnesses can be subject to brain fingerprinting examinations, as well. The American practice proves that only the perpetrators were subject to brain fingerprinting in cases reaching criminal courts. The brain fingerprinting examination of the witness may only be completed upon the witness's request, provided to avoid being suspected of a crime by the investigating authority. He would expect the examination to prove and clarify that he did not commit the criminal act, that he had not been at the crime scene, and he did not see or hear any crime-related information. Should his brain not enhance any MERMER responses, it is a strong argument against being suspected by the authority. On the other hand, if the professional examiner conducting the test comes to the conclusion that the witness's brain stores concealed information, namely, if a MERMER response is detected, it assumes to the investigating authority that the examiner tested the actual perpetrator. Of course, it supposes that the method actually works.

Both the investigating authorities and prosecutors could initiate brain fingerprinting examination of the witness, however, the test could only be concluded upon the witness's approval. Obviously, the approval actually guarantees that the test was undertaken voluntarily. Nevertheless, if the witness does agree to undertake the examination, he also accepts that its results might not be beneficial for him. The witness shall be warned that not undertaking the examination shall not be considered brain fingerprinting as damning evidence. The witness must be aware of this, and must not think that disagreeing to the examination shall not be disadvantageous for him. Even though not undertaking the test shall not be considered evidence, however, it does occur at polygraph examinations that the authorities do presume that the disapproval to

\footnotetext{
31 Act XC of 2017 on criminal procedures.
} 
test is based on the subject's fear of being identified. This issue may arise at any other device, therefore for brain fingerprinting, as well. The problem is further exaggerated by Farwell's statement, declaring that the method works with a 0 -failure rate, basing his specification on the test results concluded in laboratory circumstances, and also at the FBI, the CIA and the US Navy. In only 3\% of the cases was it questionable, whether the information was stored in the subject's brain or not. ${ }^{32}$ In other words, he could determine that the concealed information was stored in the examinee's brain in $97 \%$ of the examinations.

Should we suppose that the method is faultless, the authorities quite easily make the mistake assuming that the person disapproving to the examination might be the perpetrator. First of all, the risk of default lies in the possible injury of the guarantee, that is, not undertaking the examination must not lead to negative consequences, on the other hand, the authorities must consider the true intentions of the witness, why he did not agree to take the test. For instance, it is possible, that the witness rejects the examination having doubts on the effectivity of the method, and fears to be suspected by mistake. Another possible reason of rejecting the test for example, is that the witness who discovered the body opening the door to the crime scene and saw what happened to the victim does not inform the authorities, in fear they would not believe that he is innocent in the criminal act. Similarly, the witness discovering the body will not undertake the examination, if it is inconvenient for him that he misinformed the authority about the body found. Should the authorities take the possible reasons of rejection into consideration, wrongful assumption of guiltiness could be avoided, also, it would prevent the authorities to pursue the investigation and the entire criminal procedure on a false trail.

\section{Defendant}

According to Section 212 (1) of the IV. Be. not only the witness, but also the perpetrator can be the subject of instrumental credibility examinations. Taking the brain fingerprinting examination, the defendant may clarify and exempt himself, proving his innocence. Most probably, the defendant shall undertake the test initiated by the authority only if he is not the actual perpetrator. Overviewing the American criminal cases, we may find that the defendant did initiate the examination, in order to prove his innocence to the authorities. In case the defendant believed in the method and the device could work with a 0 -failure rate, the defendant not guilty of the crime was interested to indicate the completion of the test. However, if the defendant did commit the crime, there is certainly much less chance that he would force the conduct of the examination. This might occur if he does not believe in the operation of the method, or he tries to pull counteract means, trying to mislead the professional counsel, for example, by taking drugs prior to the examination, etc., provided that his brain should not react to the familiar visual images.

32 Farwell (2012) 115. 
In the USA, the Grinder case proved, that the defendant agreed to the brain fingerprinting examination initiated by the authority knowing that he had committed the criminal act. Presumably, in this case the defendant believed that his brain was not going to react to the familiar visuals, but it is also possible, that Grinder made his decision in the belief that rejecting the examination was going to support the suspicion that he had actually committed the crime.

\section{The Position of Brain Fingerprinting in Criminal Procedures}

While in the US, in two cases out of three the brain fingerprinting examination has been ordered to the defendant's request for a new trial for post-conviction relief, instrumental credibility examinations shall be conducted in the legal sequence of investigation, in other words, the IV. Be. does not allow brain fingerprinting neither in the criminal court procedure, nor during any procedures of extraordinary judicial remedies. The statutory provisions of the IV. Be. ruling that only professional expert counsels shall conduct instrumental credibility examination certify this principal rule, that shall apply to the brain fingerprinting examination accordingly. In compliance with the provisions of the IV. Be. the prosecutor's office shall exceptionally be entitled to involve a professional expert counsel during the court procedure, however, this opportunity shall not apply to instrumental credibility examinations, as Section 270 (1) stipulates that "Posterior to the accusation, the prosecutor shall be entitled to involve a professional expert counsel provided to pursue an evidentiary motion, to detect or to secure evidentiary means." This terminology prevents any interpretation that would allow instrumental credibility examination after the accusation.

Typically, polygraph examinations are conducted mostly on witnesses, and much more occasionally on defendants, since this aim of this method is the identification of the perpetrator during the investigation. ${ }^{33}$ Brain fingerprinting might be an adequate filtering measure, for example, to exclude the witness's criminal liability upon the results of the examination, or just to the contrary, the test results may exaggerate reasons behind the authority's suspicions. The IV. Be. differentiates two sequences of the investigation procedure, namely, the actual investigation and operational actions, whereas the latter terminates with the interrogation of the suspect. As for witnesses, the method may be conducted during both the investigative and the operative sequences. The latter is more appropriate for the identification of the examined witness as the perpetrator, or to prove that the tested witness did not conduct the criminal act, since his brain does not store any concealed information related to the criminal case. Conducting the brain fingerprinting examination during the operational sequence may also seem to be reasonable, whereas the testimony of the witness is being examined, whether he'd actually seen everything as previously stated in his testimony, since there is a chance that the witness has lied but the examination method reveals the truth and

33 Budaházi (2015) 1-118; Budaházi (2013) 90-111. 
identifies the false statements of the witness. ${ }^{34}$ Therefore, the method can efficiently prove whether the witness has seen the suspect at the crime scene or not. Brain fingerprinting is a more generally effective method of instrumental credibility examination than the polygraph, since it may not only detect, whether the witness sincerely denies the conduct of the crime, or his familiarity with the perpetrator's identity, but other segments or aspects of the testimony may also be examined. Since at the operational sequence of the criminal procedure is already passed the identification of the suspected perpetrator, consequently, conducting the brain fingerprinting examination of the witness as an instrumental credibility test at the operational stage might be more reasonable. However, completing the credibility examination during the operational period may also be reasonable, whereas this stage gives the most extensive range of possibilities to the application of the method.

Since the main subject of the operational period of the investigation is the interrogation process of the suspect, any and all other evidentiary actions shall take place at the stage of the operation, therefore, the brain fingerprinting examination of the suspect shall be conducted during the operational sequence, examining, whether the suspect has committed the criminal act and if the information related to the conduct of the crime are stored in his brain. The method may also be available to examine the suspect who pleaded guilty, but the authority assumes that he has given a false testimony, undertaking a crime that he had actually not committed.

Particularly, there was a criminal case in Hungary, where the instrumental credibility examination of the testimony could identify the individual falsely admitting the conduct of the criminal act. It was in 1980, at the early period of the polygraph's domestic application, when a taxi driver has been killed and the perpetrator took the victim's daily earnings. Several months after the conduct of the crime, a Budapest resident was taken in custody, who admitted the murder. There were several aspects of his testimony that made the proceeding authority to suspect that he did not commit the given criminal act. Finally, the suspect agreed to undergo to the polygraph examination, reassuring the authority's presumption that his statement undertaking responsibility for the crime was not sincere. After being confronted with the results of the polygraph examination, he testified again, stating that he had learned the details of the murder of the taxi driver from one of his ex-inmates in prison. Hoping that he may be granted with various benefits during his custody, he decided to make a false testimony in the taxi driver's murder case. He expected that he will be able to clear himself from the accusations before the court. ${ }^{35}$ In such cases, brain fingerprinting could be an adequate measure to examine, whether the pictures recording visual evidence of the committed criminal act enhance a MERMER response in the defendant's brain. The advantage of brain fingerprinting compared to the polygraph is that this measure does not impair fear of being detected, in other words, the issue, whether the subject who has given

\footnotetext{
Farwell (2012) 115-154.

5 Szíjártó (1990) 30-33.
} 
a false testimony fears from being detected. Actually, such threat is not necessarily stored in the defendant, furthermore, in case of the polygraph it is significant, that the examinee denies the criminal act and simultaneously fears from being identified and convicted to imprisonment. Consequently, the results of the polygraph may determine, whether the denial of the crime is sincere or not. Such conditions might not be met in case of a false confession, therefore, using an instrumental measure independent from the subject's fear from being identified might seem more adequate. Due to the lack of fear, not anyone imprisoned for another criminal act shall be a subject of a polygraph examination, since in such cases there is no actual stake of being identified, whereas he shall stay in the correction institute for several years. Brain fingerprinting might as well be the measure to solve these dilemmas, nonetheless, also applicable to check someone's alibi, as seen in the Harrington case.

\section{Doubts Related to Brain Fingerprinting}

As Rosenfeld critically found on the Harrington case, the concealed information could not be found in the convict's brain more than twenty years after the conduct of the crime, it would be a quite naïve approach to presume that Harrington did not commit the criminal action or that he was not at the scene of the crime. ${ }^{36}$ This could seem a fair presumption, moreover, it also begs the question, when has the image of the concert serving as his alibi been recorded in his brain. How could anyone be sure, that he had been at the concert right on the night when the given crime has been conducted at the car dealership? It is also questionable, whether it was enough for the subject to see the pictures and video recordings taken at the rock concert, so that his brain could store these images as concealed information, and to enhance a MERMER response to the professional expert counsel later, when examined by the brain fingerprinting method. The same doubts arise, whether the subject's response is a MERMER effect if he has seen a dead body similar to the victim's body shown during the brain fingerprinting examination in a movie, or in another case, if the victim's photo reminds the subject of one of his relatives, even causing him to fear that his relative was the victim of the crime. Moreover, it also raises the issue of the effectivity of the method, whether the examinee was under the influence of alcohol or drugs when committing the crime, or if it was dark and the visuality conditions were poor, or maybe if he is sight-impaired. These questions must be clarified, and the method should only be introduced in Hungary if accordingly tested and validated.

36 Rosenfeld (2005) 29. 


\section{Boundaries of the Admissibility of Brain Fingerprinting}

During the method, the examinee is shown photograph images, but there is also a chance that the subject is shown words. For example, the subject sees the name of the abetter or the injured party. Photos are necessary to complete the picture-image part of the examination, therefore, the test may only be conducted if the appropriate pictures related to the case are taken and accessible. This assumes that the authority has completed a successful on-site survey or search, whereas the knife used to conduct the criminal act, the body, etc. have been found. Photos are taken of these objects, however, the lack of the victim's body or the knife, and also the unknown location of the crime scene might injure the applicability of the method. In such cases, the polygraph might prove to be resentful, nevertheless, the application of the brain fingerprinting method might seem impossible. It was no accident that the defence wanted to support its post-conviction petition for a new trial with a brain fingerprinting examination in two cases, since the pictures were already accessible. However, it raises the question, if the brain produces a MERMER response if the examinee has seen the photographs used in the brain fingerprinting examination during a previous phase of the criminal procedure.

It also raises an issue, if the completion of brain fingerprinting examination at the operational stage of the investigation would make a later polygraph examination impossible. Partially, by all means, since the polygraph question sequences (General Question Test) aiming to reveal the information, whether the examinee has committed the crime or not, might be asked from the subject of the brain fingerprinting examination, however, it would significantly narrow the possibilities of the bodily knowledge based tests (Guilty Knowledge Test), because showing the crime-related pictures would result in the fact that the questions on the information projected through the visual images could not be asked in a polygraph test, since such information would be gained by the subject indirectly, not through a direct experience of committing the crime, but by seeing the photos. Consequently, if the polygraph examination is part of the investigation plan, the brain fingerprinting examination cannot prevail the polygraph.

\section{Closing Remarks}

In this study, we have come to the conclusion that there is a rather significant potential in the brain fingerprinting method, since it directly examines the brain contrary to other instrumental credibility examinations, and, as further advantages, it is capable to identify the perpetrator, furthermore, unlikely to the polygraph it can be used to check certain sequences of the testimony. We have also noted that for example, the method can be used to examine certain details of the witness, to detect, whether he had really seen what he has stated at the interview to the authority. However, we only know about three criminal cases where the method had been successfully used in the US, whereas all three cases can be connected to Farwell, who is not only the inventor but 
also the conductor of the new method. Despite the fact that the FBI, the CIA and the US Navy have tested the method with a 0 -failure rate, we must promote the completion of further experiments provided to gain more experiences on the method, before its introduction at intelligence services, in the private security sector or even in criminal cases in Hungary, similarly to its US practice. The aim of this study was to highlight the concerns related to the brain fingerprinting method, that we intend to examine and further explore in our future researches.

\section{REFERENCES}

Budaházi Árpád (2013): A poligráfos vizsgálat helye a felderítésben és a bizonyításban. Belügyi Szemle, Vol. 61, No. 11. 90-111.

Budaházi, Árpád (2015): Polygraph Examinations. Blessing or Curse. Saarbrücken, Lap Lambert Academic Publishing.

Czobor Pál - Kakuszi Brigitta - Fantoly Zsanett - Bitter István - Budaházi Árpád (2018): A büntetőeljárásban alkalmazható agyi ujjnyomat (brain fingerprinting) vallomás-ellenőrzési módszer, és annak neurobiológiai alapja, a P300 agyhullám. Magyar Rendészet, Vol. 18, No. 2. 53-67.

Farwell Brain Fingerprinting (2018a): An Overview. Available: https://larryfarwell.com/brain-fingerprinting-overview-dr-larry-farwell-dr-lawrence-farwell.html (Downloaded: 06.03.2018.)

Farwell Brain Fingerprinting (2018b): Helps to Free an Innocent Man. Available: https://larryfarwell.com/Harrington-Summary-dr-larry-farwell-brain-fingerprinting-dr-lawrence-farwell.html (Downloaded: 06.03.2018.)

Farwell Brain Fingerprinting (2018c): Catches a Serial Killer. Available: https://larryfarwell.com/ Grinder-Summary-dr-larry-farwell-brain-fingerprinting-dr-lawrence-farwell.html (Downloaded: 06.03.2018.)

Farwell, Lawrence A. (2012): Brain fingerprinting: a comprehensive tutorial review of detection of concealed information with event-related brain potentials. Cognitive Neurodynamics, Vol. 6, No. 2.115-154.

Farwell, Lawrence A. - Donchin, Emanuel (1986): The brain detector: P300 in the detection of deception. Psychophysiology, Vol. 23, No. 4. 434-450.

Farwell, Lawrence A. - Donchin, Emanuel (1991): The truth will out: interrogative polygraphy ("lie detection") with event-related brain potentials. Psychophysiology, Vol. 28, No. 5. 531-547.

Farwell, Lawrence A. - Richardson, Drew C. - Richardson, Graham M. (2013): Brain fingerprinting field studies comparing P300-MERMER and P300 brainwave responses in the detection of concealed information. Cognitive Neurodynamics, Vol. 7, No. 4. 263-299.

Fox, Dov (2008): Brain Imaging and the Bill of Rights: Memory Detection Technologies and American Criminal Justice. The American Journal of Bioethics, Vol. 8, No. 1.

Harrington v. State, 659. N.W. 2nd 509 (Iowa 2003, No. 96-1232.)

Hurd, Aaron J. (2012): Reaching Past Fingertips with Forensic Neuroimaging - Non-Testimonial Evidence Exceeding the Fifth Amendment's Grasp. Loyola Law Review, Vol. 58, No. 1.

Lumpkin, J. (2018): Slaughter v. State - Opinion. Available: https://law.justia.com/cases/oklahoma/ court-of-appeals-criminal/1997/60429.html (Downloaded: 06.03.2018.)

Lykken, David T. (1959): Properties of electrodes used in electrodermal measurement. Journal of Comparative and Physiological Psychology, Vol. 52, No. 5. 629-634.

Meijer, Ewout H. - Selle, Nathalie K. - Elber, Lotem - Ben-Shakhar, Gershon (2014): Memory detection with the Concealed Information Test: a meta analysis of skin conductance, respiration, heart rate, and P300 data. Psychophysiology, Vol. 51, No. 9. 879-904. 
Moenssens, Andre A. (2002): Brain Fingerprinting - Can It Be Used to Detect the Innocence of Persons Charged with a Crime? UMKC Law Review, Vol. 70, No. 4. 891-920.

Póczos Eszter (2006): A hazugságvizsgálat jövőképe. Belügyi Szemle,Vol. 54, No. 5. 100-109.

Rosenfeld, Joel P. (2005): 'Brain Fingerprinting': A Critical Analysis. The Scientific Review of Mental Health Practice, Vol. 4, No. 1.

Rosenfeld, Joel P. - Nasman, V. T. - Whalen, R. - Cantwell, B. - Mazzeri, L. (1987): Late vertex positivity in event-related potentials as a guilty knowledge indicator: a new method of life detection. The International Journal of Neuroscience, Vol. 34, No.1-2. 125-129.

Rosenfeld, Joel P. - Hu, Xiaoqing - Labkovsky, Elena - Meixner, John - Winograd, Michael (2013): Review of recent studies and issues regarding the P300-based complex trial protocol for detection of concealed information. International Journal of Psychophysiology, Vol. 90, No. 2. 118-134.

Slaughter (s. a.): Clark County Prosecuting Attorney: Jimmie Ray Slaughter. Available: www.clarkprosecutor.org/html/death/US/slaughter955.htm (Downloaded: 06.03.2018.)

Stoller, Sarah E. - Wolpe, Paul Root (2007): Emerging Neurotechnologies for Lie Detection and the Fifth Amendment. American Journal of Law and Medicine, Vol. 33, No. 2-3. 359-375.

Szíjărtó István (1990): A pszichofiziológiai (poligráf) vizsgálat és eredményeinek felhasználási lehetösége az élet elleni büncselekmények felderítésében. Tansegédlet. Budapest, Rendőrtiszti Főiskola. 